\title{
Enhanced growth and resistance to Vibrio challenge in pond-reared black tiger shrimp Penaeus monodon fed a Bacillus probiotic
}

\author{
Sirirat Rengpipat ${ }^{1, *}$, Aroon Tunyanun ${ }^{1}$, Arlo W. Fast ${ }^{4}$, Somkiat Piyatiratitivorakul ${ }^{2}$, \\ Piamsak Menasveta ${ }^{2,3}$ \\ ${ }^{1}$ Department of Microbiology, ${ }^{2}$ Department of Marine Science, and ${ }^{3}$ NC GEB Marine Biotechnology Research Unit, Faculty of Science, \\ Chulalongkorn University, Bangkok 10330, Thailand \\ ${ }^{4}$ Hawaii Institute of Marine Biology, University of Hawaii, PO Box 1346, Kaneohe, Hawaii 96744, USA
}

\begin{abstract}
The bacterial probiont Bacillus S11 (BS11) was used as a supplement in feed (PF) for black tiger shrimp Penaeus monodon in 2 earthen pond field-trials carried out for $100 \mathrm{~d}$ during 2 different seasons in Thailand. Growth and survival were compared with those of shrimp receiving an unsupplemented feed (UF). In the hot and cool seasons, respectively, shrimp fed PF grew significantly larger and had significantly higher survival than shrimp fed UF $(p<0.05)$. Projected yields on an annual basis (two $100 \mathrm{~d}$ crops) were $49 \%$ greater with PF-fed shrimp. In 8 d challenge tests using the luminescent bacterium Vibrio harveyi 1526, shrimp fed UF all died within $6 \mathrm{~d}$ while survival for shrimp fed PF was 5 and $9 \%$.
\end{abstract}

KEY WORDS: Marine shrimp culture - Black tiger shrimp • Pond culture $\cdot$ Penaeus monodon $\cdot$ Probiotic $\cdot$ Bacillus S11

Resale or republication not permitted without written consent of the publisher

Microbes can play both beneficial and detrimental roles in aquaculture ponds (Rheinheimer 1992, Baudin Laurencin \& Vigneulle 1994, Valiela 1995, Moriarty 1997). On the beneficial side, they are important and essential components for the nutrient and elemental cycling required to maintain water quality suitable for cultivation (Valiela 1995, Moriarty 1997). Conversely, bacteria and viruses can cause serious disease problems, with viral pathogens having the most serious economic impact on shrimp farming. Yellow head virus (YHV), white spot syndrome virus (WSSV; also known as SEMBV or systemic ectodermal and mesodermal baculovirus in Thailand) and Vibrio harveyi (cause of luminescent bacterial disease) are the 3 pathogens that account for the majority of losses in Thai shrimp culture by causing sudden and massive shrimp mortality (Flegel et al. 1992, Spaargaren 1996, Lightner \& Redman 1998).
Successful shrimp culture requires a combination of factors, including larvae free from shrimp pathogens, application of nutritious feeds, physical exclusion of disease organisms and maintenance of proper aeration and suitable pond water quality. Prophylactic, probiotic microbes are now being used widely for treatment of poultry, swine and other land animals to protect against pathogenic microbes (Fox 1988, Fuller 1989, 1999, Holzapfel et al. 1998). More recently, probiotic feeds have been developed for aquaculture but are still not widely used (Staley \& Stanley 1986, Gatesoupe 1999, Verschuere et al. 2000). This contrasts with the wide application of living bacterial supplements directly to aquaculture ponds in an attempt to control pond water quality (Boyd \& Gross 1998). By definition (Fuller 1989, 1992, 1997, Tannock 1999), bacteria added directly to pond water are not probiotics and should not be compared to living microbes added to feed. Potential benefits from the use of true probiotics (i.e. microbes added to feed) include protection against bacterial and viral pathogens for which there are no medications and replacement of chemicals such as antibiotics that may create problematic residues in products intended for human consumption.

We previously isolated the bacterium Bacillus S11 (BS11) and demonstrated its probiotic properties with black tiger shrimp Penaeus monodon in small laboratory aquaria (Rengpipat et al. 1998). P. monodon receiving BS11-supplemented feed (PF) had better survival after bacterial challenge tests and showed a heightened immune response when compared with control shrimp fed unsupplemented feed (UF) (Rengpipat et al. 2000). Here we describe field trials in earthen ponds carried out in a similar manner to the laboratory trials in order to test efficacy of BS11 in conditions of 
commercial growout ponds. PF- and UF-fed shrimp were held in cages in the same culture pond to insure similar environmental conditions for all treatments. Growth, survival, and disease resistance were evaluated in laboratory challenge tests following pond culture.

Materials and methods. Bacteria: We previously isolated BS11 from the gastrointestinal tract of Penaeus monodon broodstock and demonstrated its efficacy as a probiotic for P. monodon in laboratory trials (Rengpipat et al. 1998). In this study BS11, stored on tryptic soy agar (TSA; Difco) was cultured in tryptic soy broth (TSB; Difco) shaken at $200 \mathrm{rpm}$ in an incubator at $30^{\circ} \mathrm{C}$ for $24 \mathrm{~h}$. Cells were harvested by centrifugation $(8000 \mathrm{rpm}, 7310 \times g)$ at $4^{\circ} \mathrm{C}$ for $15 \mathrm{~min}$ and washed 3 times in sterile, normal saline solution $(0.85 \% \mathrm{NaCl})$ before being resuspended in the same. Culture purity and identity were routinely checked during preparation by confirmatory biochemical tests (API $50 \mathrm{CH}$, Bio Merieux) and by monitoring the unique and specific physical appearance of BS11 on TSA (Rengpipat et al. 1998).

Challenge tests: Challenge tests were conducted with Vibrio harveyi 1526 isolated from Penaeus monodon dying of luminescent disease and kindly provided by the Shrimp Culture Research Center, Charoen Pokphand Feedmill, Samutsakorn, Thailand. It was cultured at $30^{\circ} \mathrm{C}$ in TSB or on TSA containing $2 \% \mathrm{NaCl}(\mathrm{w} / \mathrm{v})$ and identity was confirmed as described by Baumann \& Schubert (1984). Presumptive concentrations or colony-forming units (CFU) of Vibrio spp. were determined using spread plates of thiosulfate citrate bile sucrose agar (TCBS, Difco). Cells were harvested from TSB after 18 to $24 \mathrm{~h}$ by centrifugation $(8000 \mathrm{rpm}, 7310 \times \mathrm{g})$ at $4{ }^{\circ} \mathrm{C}$ for $15 \mathrm{~min}$, followed by 2 washes of sterile $2 \%$ saline. Bath challenges with $V$. harveyi 1526 were conducted by adding $\sim 10^{11} \mathrm{CFU} \mathrm{g}{ }^{-1}$ to aquaria in appropriate weight to obtain a final cell concentration of $\sim 10^{7} \mathrm{CFU} \mathrm{ml} l^{-1}$ of aquarium water.

Shrimp feeds: Shrimp were fed a commercially formulated, unsupplemented control feed (UF) purchased from Grobest, Thailand. For the supplemented test feed (PF), $1 \mathrm{~kg}$ wet wt ( 100 g dry wt) of BS11 $\left(\sim 10^{10}\right.$ $\mathrm{CFU} \mathrm{\textrm {g } ^ { - 1 }}$ ) was thoroughly mixed with $3 \mathrm{~kg}$ of feed (i.e. approximately $2.5 \%$ content BS11/total wt). The PF mixture was air-dried for 1 to $2 \mathrm{~h}$ at $28^{\circ} \mathrm{C}$ and stored in clean, plastic bags at $4^{\circ} \mathrm{C}$. Shrimp feed was prepared twice weekly and each batch was analyzed for BS11 and total bacterial count.

Cage Trial 1: Hatchery-reared Penaeus monodon of 0.6 to $0.9 \mathrm{~g}$ body wt were stocked into twenty-four $2 \mathrm{~m}^{2}$ net cages ( $1.0 \mathrm{~mm}$ mesh) at 80 shrimp per cage. Cages were placed at $1.3 \mathrm{~m}$ water depth in one $500 \mathrm{~m}^{2}$ pond along an access walkway. Cages were suspended
$20 \mathrm{~cm}$ above the pond bottom and extended $40 \mathrm{~cm}$ above the water surface. Twelve cages contained control shrimp fed UF while treated shrimp in the remaining 12 cages were fed a combination of PF and UF. Individual cages were separated by a distance of approximately $1 \mathrm{~m}$. Rows of test and control cages were separated by a distance $1.5 \mathrm{~m}$ on opposite sides of the walkway. Pond water salinity was $8 \%$ at trial initiation in June 2000 and decreased to $4 \%$ after $100 \mathrm{~d}$ of culture ending in September 2000 (Thai hot season). Pond water was aerated and under closed-system operation. All shrimp were fed 3 times daily at $10 \%$ body weight. Treated shrimp received 2 UF applications and $1 \mathrm{PF}$ application daily, while control shrimp received 3 UF applications per day. Shrimp survival and weights were measured every $20 \mathrm{~d}$ beginning at Day 1. Eight shrimp per cage (total 96 shrimp per treatment) were randomly sampled at individual time points for weight measurements and then brought back to their original cages. During the trial, water temperature and $\mathrm{pH}$ were measured daily inside the cages, while salinity, dissolved oxygen, ammonium, nitrite, phosphorus and alkalinity were measured every $20 \mathrm{~d}$ as described by Rengpipat et al. (2000).

Cage Trial 2: Conditions were nearly identical to those in Trial 1 with respect to shrimp stocking densities, test pond, feeding, monitoring and culture time. Trial 2 differed by being conducted during a different season (Thai cool season) from November 2000 until February 2001 and by having only 12 cages with 6 UF and 6 PF groups of shrimp stocked at a smaller size of $0.4 \mathrm{~g}$.

Vibrio challenge test: After the $100 \mathrm{~d}$ feeding trials and before challenge, UF- and PF-fed shrimp were acclimatized for $1 \mathrm{wk}$ in concrete aquaria $\left(0.8 \mathrm{~m}^{2}\right.$ with 1801 water). Static disease challenges were conducted on the groups of shrimp using a single initial exposure to the luminescent bacterium Vibrio harveyi 1526. Average wet weights of shrimp started at $\sim 18 \mathrm{~g}$. During acclimatization, aquarium water salinity was gradually increased by 2 to $20 \% \mathrm{~d}^{-1}$ while the feeding regime was the same as in Trials 1 and 2. Each challenge test included 12 aquaria with a $2 \times 2$ factorial design. Treatments included PF- and UF-fed shrimp challenged with $V$. harveyi, and unchallenged PF- and UF-fed control shrimp. Treatments were done in triplicate with each aquarium containing 18 shrimp.

Shrimp were challenged by bath exposure to Vibrio harveyi 1526 in aquarium water at $\sim 10^{7} \mathrm{CFU} \mathrm{ml}{ }^{-1}$ according to Austin et al. (1995) and modified by Rengpipat et al. (1998). No water was exchanged thereafter for the duration of the $8 \mathrm{~d}$ trial. During challenge tests, water quality parameters and shrimp survival were measured every $2 \mathrm{~d}$ as in the field trials. Shrimp samples and $200 \mathrm{ml}$ water from the challenge aquaria were 
Fig. 1. Penaeus monodon. Average weights of shrimp fed BS11fortified feed (Probiotic) or feed without BS11 (Control). Each treatment group included 12 cages in Trial 1 and 6 cages in Trial 2. ${ }^{*}$ Significant differences $(\mathrm{p}<0.05)$

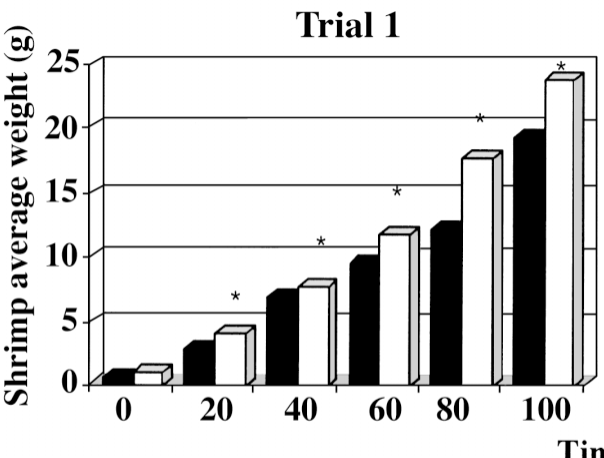

Trial 1

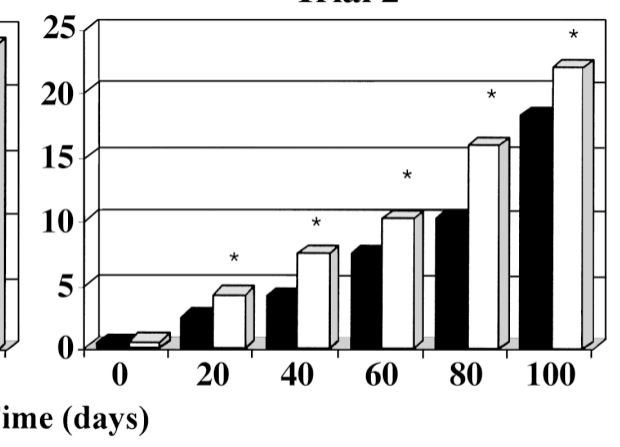

Control ( $\square$ ) Probiotic ( $\square$ ) randomly collected for detection of $V$. harveyi 1526 and BS11. On Day 0 after exposure to $V$. harveyi 1 live shrimp from each challenge aquarium, and 3 shrimp immediately after death at 2, 4, 6, and $8 \mathrm{~d}$ post-exposure were collected for microbial enumeration. The cumulative number of dead shrimp was recorded each day and by Day 6, all of the UF-fed shrimp challenged with $V$. harveyi had died. For every dead shrimp, the hepatopancreas-intestine was dissected and examined for the presence of $V$. harveyi 1526 initially by isolation on TCBS agar and followed by identification as $V$. harveyi as described above. CFU from aquarium water were determined in triplicate for each treatment by serial dilution of $1 \mathrm{ml}$ from each aquarium in normal saline for inoculation $(0.1 \mathrm{ml})$ on spread plates of TCBS for $V$. harveyi 1526 and TSA for BS11. Quantitative bacterial counts from the hepatopancreas-intestine were made from dissected and weighed pieces of tissue suspended in sterile saline and homogenized for inoculation onto spread plates as described above.

Statistics: Effects of BS11 on shrimp growth, survival and disease resistance in respective trials were evaluated using 1-way analysis of variance and Duncan's multiple range tests (Statistical Analysis System 1983) with $\mathrm{p}<0.05$ as the confidence level for significant differences.

Results and discussion. Cage trials: Penaeus monodon fed PF in net pens had significantly greater sur-

Table 1. Penaeus monodon. Mean survivals of shrimp fed BS11-supplemented feed (PF) or unsupplemented feed (UF) (Control). Each treatment group included 12 cages in Trial 1 and 6 cages in Trial 2. ${ }^{*}$ Significant difference $(p<0.05)$ between groups in the same trial

\begin{tabular}{|c|c|c|}
\hline \multirow[t]{2}{*}{ Treatment } & \multicolumn{2}{|c|}{ Survival (\%) } \\
\hline & Trial 1 & Trial 2 \\
\hline Control (UF) & $65 \pm 11.5$ & $62.5 \pm 7.5$ \\
\hline Probiotic (PF) & $76.6 \pm 6.2^{*}$ & $86.8 \pm 5.0^{*}$ \\
\hline
\end{tabular}

vival (Table 1) and weights (Fig. 1) $(p<0.05)$ in both cage trials when compared with shrimp fed UF only. Significant weight differences began at $20 \mathrm{~d}$ after the start of both trials (Fig. 1). After 100 d, mean weights of PF-fed shrimp were $25.4 \pm 2.5$ (average daily gain [ADG] $=0.25)$ and $22.0 \pm 1.2 \mathrm{~g}(\mathrm{ADG}=0.22)$ in Trials 1 and 2 , respectively, compared with $18.6 \pm 0.8(\mathrm{ADG}=$ $0.18)$ and $18.3 \pm 0.6 \mathrm{~g}(\mathrm{ADG}=0.18)$ for the corresponding controls. Combined average weights and survivals from Trials 1 and 2 were $23.7 \mathrm{~g}(\mathrm{ADG}=0.235)$ and $81.7 \%$ for PF-fed shrimp and $18.5 \mathrm{~g}(\mathrm{ADG}=0.18)$ and $63.8 \%$ for UF-fed controls. This represents a $30 \%$ higher ADG and $28 \%$ higher survival than the control. Projected yields $\mathrm{m}^{-2}$ crop were 968 and $590 \mathrm{~g}$ for PFand UF-fed shrimp, respectively, and would translate into 9681 and $5902 \mathrm{~kg} \mathrm{ha}^{-1}$ crop, respectively. These results indicate that the benefits of BS11 feed supplementation seen in laboratory tests (Rengpipat et al. 1998, 2000) can also be obtained in field trials conducted under normal commercial farming conditions. Based on our current small-scale production costs, we estimate that BS11 supplementation would increase shrimp rearing costs by approximately US\$ $0.12 \mathrm{~kg}^{-1}$ of fresh weight shrimp produced.

Water temperatures and other water quality values were essentially the same between cages in each trial. Water temperatures at 10:00 and 13:00 h ranged from 26 to 28 and 29.5 to $31^{\circ} \mathrm{C}$, respectively, for Trial 1 and 23.5 to $24.5^{\circ} \mathrm{C}$ and 29.5 to $31.5^{\circ} \mathrm{C}$, respectively, for Trial 2. The $\mathrm{pH}$ ranged from 7.4 to 8.4 for both trials while salinity ranged between 3 and $4 \%$ for Trial 1, and from 4 to $5 \%$ o for Trial 2. Dissolved oxygen from both trials was never less than $5.7 \mathrm{mg} \mathrm{l}^{-1}$, while maximum values for ammonium, nitrite, and phosphorus were $0.05,0.25$ and $0.25 \mathrm{mg} \mathrm{l}^{-1}$, respectively. Total alkalinity ranged from 90 to $140 \mathrm{mg} \mathrm{l}^{-1}$ for both.

Vibrio challenge test: Penaeus monodon fed UF in cage Trials 1 and 2 sustained $100 \%$ mortality within 6 d after challenge with Vibrio harveyi 1526 (Fig. 2). Higher mortality began at Days 2 and 3, reaching 70 to 
Trial 1

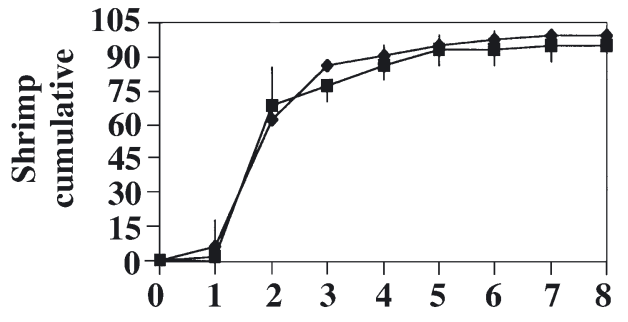

Trial 2

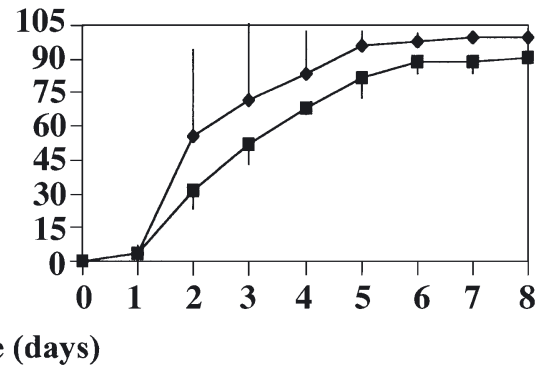

Control (- $\bullet$-) Probiotic (-口-)

Fig. 2. Penaeus monodon. Cumulative mortality of shrimp from Trials 1 and 2 during $8 \mathrm{~d}$ challenges with Vibrio harveyi 1526. Values are the means of 3 replicates per treatment. No mortality occurred in the 2 control groups without $V$. harveyi 1526 . Vertical bars indicate mean - SD
$90 \%$ by Day 3 and $100 \%$ by Day 6 . PF-fed shrimp also experienced high mortality, but the total was less than $100 \%$ by Day 8 and it was also less severe than for UFfed shrimp at onset, reaching 45 to $75 \%$ by Day 3 . Survival was $100 \%$ in the unchallenged control shrimp.

For PF-fed shrimp from Trials 1 and 2, BS11 was present in challenge aquaria water at $10^{3}$ to $10^{5} \mathrm{CFU}$ $\mathrm{ml}^{-1}$ but it was undetectable in aquaria with UF-fed control shrimp. Concentrations of Vibrio harveyi 1526 decreased sharply from $\sim 10^{7} \mathrm{CFU} \mathrm{mm^{-1 }}$ to $10^{3}$ to $10^{4}$ CFU ml $\mathrm{m}^{-1}$ by Day 2 and remained steady thereafter in both challenge tests.

Counts of BS11 in hepatopancreas-intestines of PFfed shrimp were $10^{4}$ to $10^{6} \mathrm{CFU} \mathrm{g}{ }^{-1}$ before challenge but decreased by nearly 2 logs after Vibrio harveyi challenge (Fig. 3). BS11 was undetectable in UF-fed shrimp (Fig. 3). Counts for $V$. harveyi 1526 increased from zero prior to challenge to near $10^{6} \mathrm{CFU} \mathrm{g}^{-1}$ imme- diately after challenge and then stabilized around $10^{5}$ CFU $\mathrm{g}^{-1}$ from Day 2 until Day 8 for PF-fed shrimp and until Day 6 (100\% cumulative mortality) for the UF-fed shrimp.

Water quality values were nearly the same between aquaria in each challenge test. Water temperatures ranged from 24.5 to $29.5^{\circ} \mathrm{C}$ for the first challenge and from 23 to $28^{\circ} \mathrm{C}$ for the second, while $\mathrm{pH}$ ranged from 7.4 to 8.2 for both. Dissolved oxygen was never less than $4.9 \mathrm{mg} \mathrm{l}^{-1}$ in any aqarium. Ammonium, nitrite, phosphorus and alkalinity increased during the challenge tests. In Trial 1, ammonium increased from $0.5 \mathrm{mg} \mathrm{l}^{-1}$ to as much as $5 \mathrm{mg} \mathrm{l}^{-1}$ while that for Trial 2 increased from $\leq 0.15 \mathrm{mg} \mathrm{l}^{-1}$ to as much as $6.5 \mathrm{mg} \mathrm{l}^{-1}$. Nitrite increased from $\leq 0.08$ to $2.5 \mathrm{mg} \mathrm{l}^{-1}$ in Trial 1 and from $\leq 0.05$ to 2.5 or $3.5 \mathrm{mg} \mathrm{l}^{-1}$ in Trial 2. Phosphorus ranged from 3 to $10 \mathrm{mg} \mathrm{l}^{-1}$ while alkalinity ranged from 102 to $153 \mathrm{mg} \mathrm{l}^{-1}$ in both tests.
Fig. 3. Penaeus monodon. Bacterial counts of (A) Vibrio harveyi 1526 and (B) Bacillus S11 in hepatopancreas-intestines during $8 \mathrm{~d}$ of challenge with $V$. harveyi 1526 for shrimp fed BS11 fortified feed PF (Probiotic) or non-fortified feed UF (Control). Values are means of 3 replicates per treatment while $(\downarrow)$ indicates when $100 \%$ mortality occurred in the control group
A
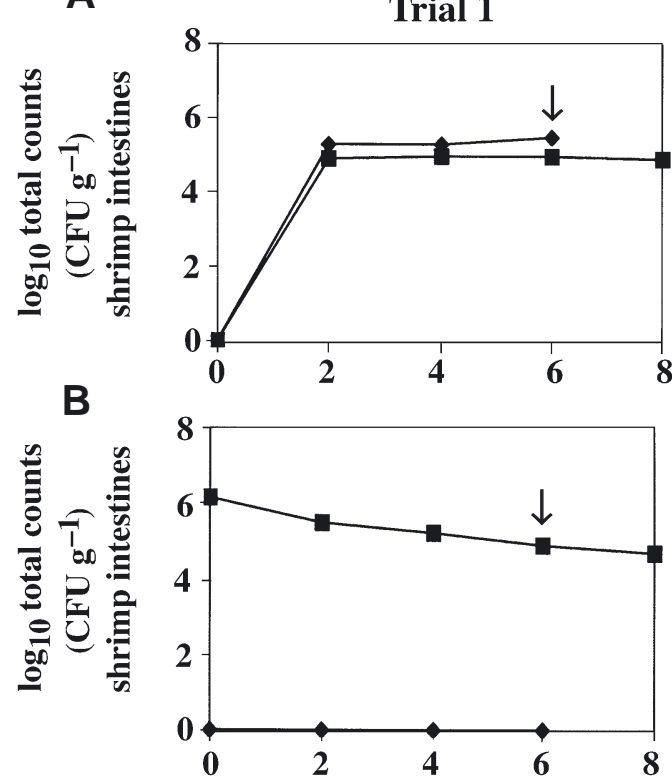

Trial 2
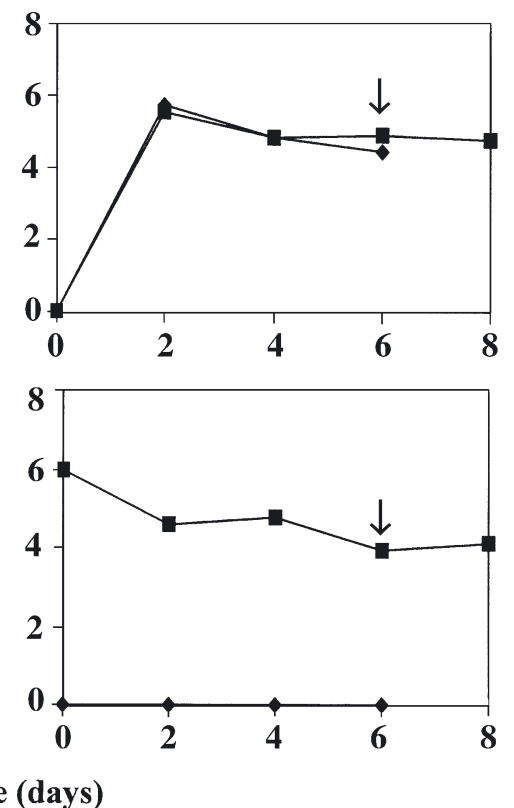

Time (days)

Control (- -) Probiotic (-ם-) 
Although marginal, the protective effect of BS11 against Vibrio harveyi challenge observed here in field trials was consistent with results from our earlier laboratory studies (Rengpipat et al. 1998, 2000) where protection was more pronounced. Possibly a more pronounced difference would have occurred with a lower challenge dose. Indeed, the challenge concentration of $\sim 10^{7} \mathrm{CFU} \mathrm{ml} \mathrm{m}^{-1}$ of $V$. harveyi was far greater than that typically reported in production ponds during luminescence disease outbreaks (Ruangpan 1998). Additionally, removal of the shrimp from the $100 \mathrm{~d}$ cage trial at low salinity (4\%) and acclimatization to a higher salinity $(20 \%$ ) allowing survival and growth of $V$. harveyi 1526 in the bath challenge may have stressed the shrimp, altering their defense capability. In addition, the ammonia and nitrite concentrations in the challenge trials were much higher than those in the ponds from which the shrimp were taken. Stress can increase the host susceptibility to pathogens even of low virulence (Song et al. 1993). Perhaps there should have been a longer period of acclimatization or measures taken to keep ammonium and nitrite levels lower. In future tests, variables could be reduced by conducting growth and challenge phases at the same salinity. This would involve growing the shrimp at higher salinity or selecting a challenge bacterium that can be used at low salinity. Regardless, the survival rates in our challenge test would not be acceptable in a farm situation and further tests are required to determine whether BS11 can improve resistance to bacterial challenge in a pond setting. However, the significantly higher survival and ADG of PF-fed versus UF-fed shrimp argues that the former were in better health, and improved health is generally associated with improved defense capability.

Acknowledgements. This research was supported by the Thailand Research Fund, and the Local Graduate Scholarship by the National Science and Technology Development Agency, Thailand.

\section{LITERATURE CITED}

Austin B, Stuckey LF, Robertson PAW, Effendi I , Griffith DRW (1995) A probiotic strain of Vibrio alginolyticus effective in reducing diseases caused by Aeromonas salmonicida, Vibrio anguillarum and Vibrio ordalii. J Fish Dis 18:93-96

Baudin Laurencin F, Vigneulle M (1994) Diseases in aquaculture operations. In: Barnabé G (ed) Aquaculture biology and ecology of cultured species. Ellis Horwood, New York, p 373-390

Baumann P, Schubert RHW (1984) Vibrionaceae. In: Krieg NA, Holt JG (eds) Bergey's manual of systematic bacteriology, Vol 1. William \& Wilkins, Baltimore, p 516-549

Boyd CE, Gross A (1998) Use of probiotics for improving soil and water quality in aquaculture ponds. In: Fulks W, Main

Editorial responsibility: Timothy Flegel,

Bangkok, Thailand
KL (eds) Diseases of cultured penaeid shrimp in Asia and the United States. The Oceanic Institute, Honolulu, HI, p 101-106

Flegel TW, Fegan DF, Kongsom S, Vuthikomudomkit S, Sriurairatana S, Boonyaratpalin S, Chantanachookhin C, Vickers JE, Macdonald OD (1992) Occurrence, diagnosis and treatment of shrimp diseases in Thailand. In: Fulks W, Main KL (eds) Diseases of cultured penaeid shrimp in Asia and the United States. The Oceanic Institute, Honolulu, HI, p 57-112

Fox SM (1988) Probiotic:intestinal inoculants for production animals. Vet Med 83:806-830

Fuller R (1989) Probiotics in man and animals. J Appl Bacteriol 66:365-378

Fuller R (1992) Probiotics: the scientific basis, 1st edn. Chapman \& Hall, London

Fuller R (1997) Probiotics 2: applications and practical aspects 1st edn. Chapman \& Hall, London

Fuller R (1999) Probiotics for farm animal. In: Tannock GW (ed) Probiotic: critical review. Horizon Scientific Press, Norfolk, p 15-22

Gatesoupe F J (1999) The use of probiotics in aquaculture. Aquaculture 180:147-165

Holzapfel WH, Harberer P, Snel J, Schillinger U, Huis in't Veld JHJ (1998) Overview of gut flora and probiotics. Int J Food Microbiol 41:85-101

Lightner DV, Redman RM (1998) Shrimp diseases and current diagnostic methods. Aquaculture 164:201-220

Moriarty DJW (1997) The role of microorganisms in aquaculture ponds. Aquaculture 151:333-349

Rengpipat S, Phianphak W, Piyatiratitivorakul S, Menasveta P (1998) Effect of a probiotic bacterium on black tiger shrimp Penaeus monodon survival and growth. Aquaculture 167:301-313

Rengpipat S, Rukpratanporn S, Piyatiratitivorakul S, Menasveta P (2000) Immunity enhancement in black tiger shrimp (Penaeus monodon) by probiont bacterium (Bacillus S11). Aquaculture 191:271-288

Rheinheimer G (1992) Pathogens in aquatics plants and animals and their control. In: Rheinheimer G (ed) Aquatic microbiology, 4th edn. John Wiley \& Sons, Guildford, p 175-249

Ruangpan L (1998) Luminous bacteria associated in shrimp mortality. In: Flegel TW (ed) Advance in shrimp biotechnology. Proc Special Session on Shrimp Biotechnology 5th Asian Fisheries Forum, Chiengmai, Thailand. John Wiley \& Sons, Guildford, p 205-211

Song YL, Cheng W, Wang CH (1993) Isolation and characterization of Vibrio damsela infectious for cultured shrimp in Taiwan. J Invertebr Pathol 61:24-31

Spaargaren DA (1996) Disease in cultures of tiger prawns, Penaeus monodon Fabricius, 1798. Crustacean 69: 1018-1024

Staley JT, Stanley PM (1986) Potential commercial applications in aquatic microbiology. Microb Ecol 12:79-100

Statistical Analysis System (1983) SAS introductory guide. SAS Institute, Cary, NC

Tannock, GW, Fuller R, Pedersen K (1999) Lactobacillus succession in the piglet digestive tract demonstrated by plasmid profiling. Appl Environ Microbiol 56:1310-1316

Valiela I (1995) The carbon cycle: production and transformation of organic matter. In: Flegel TM (ed) Marine ecological processes, 2nd edn. Multimedia Asia, Bangkok, p 385-461

Verschuere L, Rombaut G, Sorgeloos P, Verstraete W (2000) Probiotic bacteria as biological control agents in aquaculture. Microbiol Mol Biol Rev 64:655-671

Submitted: April 14, 2002; Accepted: May 1, 2003

Proofs received from author(s): June 5, 2003 